\title{
Motivation of Employees of Transport and Logistics Companies in the Czech Republic and in a Selected Region of the PRC
}

\author{
Lenka Ližbetinová ${ }^{1, *}$, Miloš Hitka ${ }^{2}$, Chenguang Li $^{3}$, and Zdeněk Caha ${ }^{1}$ \\ ${ }^{1}$ Institute of Technology and Economics in České Budějovice, Faculty of Business Strategy, Okružní \\ 517/10, 37001 České Budějovice, Czech Republic \\ ${ }^{2}$ Technical University in Zvolen, Faculty of Wood Sciences and Technology, Masaryka 24, 96053 \\ Zvolen, Slovak Republic \\ ${ }^{3}$ North China University of Technology, School of Economics and Management, No.5 Jinyuanzhuang \\ Road, Shijingshan District, Beijing 100144, P. R. China
}

\begin{abstract}
Improvement of employee performance is an inseparable part of an enterprise. It ensures the fulfilment of goals and the company profitability. The main goal of the paper is to present the results of a research focused on comparison of the motivation factors of employees of transport and logistics companies in selected regions. The research carried out in 2017 examined the level of the motivation in the conditions of transport and logistics companies in the Czech Republic and the Peking Municipality in the PRC. These territories have different historic and cultural backgrounds, which leads to a high assumption of the existence of different views of the importance of motivation factors not only in the sphere of transport. The contribution also brings comparison of the preferences from the gender point of view.
\end{abstract}

\section{Introduction}

Intellectual capital is usually defined as the sum of the resources of a company. It includes knowledge, information, intellectual property, experience and human resources that might contribute to the production of the wealth of a company [1]. Intellectual capital consists of three basic mutually linked components, namely the human capital, the structural capital and the relational capital [2]. Human capital represents the human factor in a company [3, 4]. It is a combination of intelligence, skills and knowledge that it can provide to the company. Researchers claim that human capital is the most important value of a company, as it is the resource of creativity, brings new innovations, changes and improvements [5]. Companies often concentrate on the human capital as a source of new possibilities and innovation [6].

Human capital also brings the emotional relation to a company. A psychological contract is an emotional relation between an employer and an employee and in measures the organization commitment [7]. The psychological contract origins from the works by

* Corresponding author: lizbetinova@mail.vstecb.cz 
Argyris [8], who used this term to describe the relation between a group of employees and their superior. Rousseau [9] considers the psychological research to the mental models of employees, mutuality and effectiveness the basic elements of psychological theories. A psychological contract consists of two factors. Employee satisfaction is the first one and employee commitment is the other. Both these factors capture the emotional relation of individual employees to their organization.

Managers have an unenviable and difficult role. The factors that motivate a manager do not necessarily motivate his/her employees. It is necessary to view each employee individually $[10,11]$. Each employee is different and unique in terms of the age, education, needs and expectations. All that has to be taken into account in the right motivation of employees [12]. Motivation supports the success of employees in their fields and their coping with the everyday tasks $[13,14]$. With the aim to improve the general organizational abilities and meeting the company goals managers have to manage employees adequately and smoothly, to achieve the required work success [15]. The monitoring of and the support for the individual achievements is an important precondition of the monitoring and strengthening of the overall success of the business system. [6, 16].

These general rules also apply to the environment of transport [17] and logistic companies [18]. Their specifics (the specifics of transport services) however create a precondition determining modifications within employee motivation [19]. Transporting and logistic companies employed $6.9 \%$ of the economically active people in the Czech Republic in 2015, of which $74.1 \%$ were men [20], and $71 \%$ in Slovakia, while the proportion of men was $76.5 \%$ there [21]. Numerous companies fight with the lack of quality human resources and look for the possibilities how to cover this deficit [22]. Another problem they also face is, how to hold the quality labour force that has proven to be useful and is trained. The identification of what these employees prefer in the work relations and what motivates them to a higher performance and what, on the other hand, demotivates them, is the answer [23, 24].

Our research focuses on the motivation factors of employees in the environment of transport companies active in the CR, compared with the employee preferences ascertained in the Peking Municipality in China. The distribution sphere in China, a continuously growing world producer, does not lag behind the production. This requires a strong logistic background. This sphere is also characterized by a higher economic level, which has influence on the traditional Chinese values and attitudes. This homogeneous Asian society is particularly characterized by a strong power distance, the seniority principle, strong interpersonal relations, collectivism and higher corruption rate [25]. The original traditional social patterns are dodging a modern business environment. It is therefore more likely that there are employees with similar preferences in motivation in this territory than in less developed territories of the PRC. On the other hand, the Czech Republic is a country that passed the transformation from the original communist regime to the market economy conditions. It is characterized by Central-European culture, which also influences the employee preferences in an employment to a high extent [26].

\section{Material and methods}

The aim of our contribution is to compare the levels of the preferences of motivation factors between employees of transporting and logistic companies in the Czech Republic and in the Peking Municipality. The gender of the respondents is taken into account in the comparison. With regard to the different social roles and attitudes we examined which motivation factors have stronger influence on women and which have stronger influence on men. The paper focuses on looking for the differences in the motivation factors between the genders and the different nationalities of the employees, which affect their performance. 
The contribution is based on the data obtained through questionnaires distributed personally during 2017. The questionnaires [27] are divided into two basic parts, where the first part deals with the respondents' personal details (age, gender, years with the company, achieved education and the company size). Table 1 presents the structure of both the sample sets, from the Czech Republic and from the Peking Municipality in the PRC. The second part is dedicated to the evaluation of the importance and the fulfilment of the motivation factors from the respondent's point of view. 30 motivation factors in total were evaluated my means of the Likert scale from 1 to 5 (where 1 meant unimportant/dissatisfied and 5 meant very important/very much satisfied).

The respondents were chosen by a random choice method from among the employees of transporting and logistic companies from both the countries. The data comparison was carried out by means of the weighted arithmetic means. Within the data evaluation we also used mathematic-statistic comparison by means of a two-sample T-test. Two-sample T-test is applied to the evaluation of various experiments where we do not know the mean value of the basic set and we only know two sets of selected data. Student's T-test for dependent samples tests the hypothesis of the average distribution of the pair values. The test is usually used to verify whether the average difference of pairs ascertained from samples can be only random (the variables are independent) or it is statistically significant (the variables are dependent). An interval estimation of the mean pair difference provides more information than the test itself, as it determines the limits within which the real mean difference occurs with the required confidence (probability, most frequently $95 \%$ ) [28].

Table 1. Characteristics of respondents. Source: authors

\begin{tabular}{|c|c|c|c|}
\hline & & Czech Republic & Peking Municipality \\
\hline & & Number of respondents & Number of respondents \\
\hline \multirow{2}{*}{ 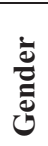 } & Male & 632 & 430 \\
\hline & Female & 538 & 469 \\
\hline \multirow{5}{*}{$\stackrel{50}{4}$} & less than 30 years & 373 & 483 \\
\hline & $31-40$ years & 294 & 231 \\
\hline & $41-50$ years & 313 & 139 \\
\hline & over 50 years & 190 & 46 \\
\hline & Total & 1170 & 899 \\
\hline
\end{tabular}

\section{Results and discussion}

In Table 3, we can see which groups of motivation factors influence the categories of women and men with regard to the nationality. In table 2, we can see which group of motivation factors most influences employees of transporting and logistic companies and their work performance in the Czech Republic and in the region in Peking. The highest stress is put on the relational motivation factors in both the nationalities. We can therefore state that both the nationalities improve the work performance if they feel good at the workplace, have good relation with their colleagues and their superiors are a support to them. Financial motivation factors are the second most important group. If employees are sufficiently and fairly appraised, they increase their work performance. Nevertheless, focusing solely on the aspect of an increase of finance might lead to a worse attitude to work among employees, as they might only be driven by financial incomes (Baldoni, 2005). Among Czech employees of transporting and logistic companies the work factors 
are the third most important group, while among the respondents from the Peking Municipality there are the career aspects. Employees can be motivated by the opportunity to apply their own abilities, they want to educate themselves, self-actualize and they can be motivated by recognition by their superiors. Employees are least influenced by the company vision, the development of the region, communication of the company performance and the company's relation to the environment. The difference between men and women in the comparison of the basic motivation groups is minimum in both nationalities.

Table 2. Comparison of motivational factor types by gender and nationality (in weighted arithmetic mean). Source: authors

\begin{tabular}{|c|c|c|c|c|c|c|c|c|c|c|}
\hline Factors & \multicolumn{2}{|c|}{ Career } & \multicolumn{2}{|c|}{ Work } & \multicolumn{2}{|c|}{ Social } & \multicolumn{2}{|c|}{ Relational } & \multicolumn{2}{|c|}{ Financial } \\
\hline Region & 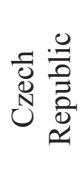 & 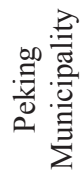 & 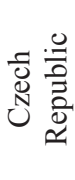 & 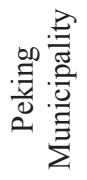 & 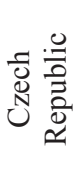 & 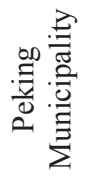 & 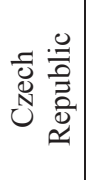 & 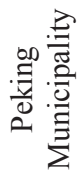 & 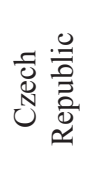 & 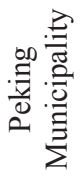 \\
\hline Total & 3.93 & 4.01 & 4.03 & 3.97 & 3.79 & 3.93 & 4.37 & 4.13 & 4.26 & 4.09 \\
\hline Women & 3.92 & 4.02 & 4.07 & 4.01 & 3.78 & 3.99 & 4.45 & 4.17 & 4.34 & 4.12 \\
\hline Men & 3.94 & 4.00 & 4.01 & 3.93 & 3.79 & 3.87 & 4.31 & 4.09 & 4.19 & 4.05 \\
\hline
\end{tabular}

Table 3 present the analysis of employees of transporting and logistic companies from the territories of the Czech Republic and the Peking Municipality from the gender point of view. The part 1 of Table 3 compares the influence of motivation factors on men and women working in the transportation sphere in the Czech Republic. As we can see, both genders are motivated to the best work performance by the atmosphere at the workplace. From the above-mentioned facts, we can conclude that the friendlier the atmosphere at the workplace is the more effective the employees are for the company. The relational motivation factors can most efficiently influence the increase of the employee performance according to the results. The difference between men and women is particularly visible in the opportunity to apply one's own abilities and the elimination of stress at the workplace.

Men are motivated to better work performance by the opportunity to apply their own abilities and women care more about the elimination of stress at the workplace. Recognition is another factor in which the genders differ. Women need recognition. It motivates them to better performance. They try to work as efficiently as possible to achieve recognition. Men are not motivated by recognition to such an extent as women. They care more about independent decision making and self-actualization. These results lead us to an idea, namely that women need a support from their colleagues, recognition from their superiors and the environment to increase their work performance. Unlike men, who want to decide independently and are motivated by self-actualization and their own ideas, they want to be of benefit to the company. The motivation factors that do not have a special influence on the employee performance are more or less the same among men and women. They are mainly the social factors, like the company's relation to the environment, the region development, the company vision, the prestige of the company, but also the physical effort at work and the prestige of the position. 
Table 3. Motivational factor preference in the Czech Republic and the Peking Municipality by gender. Source: authors

\begin{tabular}{|c|c|c|c|c|c|c|c|}
\hline \multicolumn{4}{|c|}{ Czech Republic } & \multicolumn{4}{|c|}{ Peking Municipality } \\
\hline \multicolumn{2}{|l|}{ Men } & \multicolumn{2}{|l|}{ Women } & \multicolumn{2}{|c|}{ Men } & \multicolumn{2}{|l|}{ Women } \\
\hline $\begin{array}{l}\text { Atmosphere in } \\
\text { the workplace }\end{array}$ & 4.45 & $\begin{array}{c}\text { Atmosphere in the } \\
\text { workplace }\end{array}$ & 4.53 & Good work team & 4.15 & Good work team & 4.23 \\
\hline $\begin{array}{l}\text { Supervisor's } \\
\text { approach }\end{array}$ & 4.37 & $\begin{array}{c}\text { Supervisor's } \\
\text { approach }\end{array}$ & 4.52 & $\begin{array}{l}\text { Atmosphere in the } \\
\text { workplace }\end{array}$ & 4.12 & $\begin{array}{c}\text { Atmosphere in the } \\
\text { workplace }\end{array}$ & 4.22 \\
\hline $\begin{array}{l}\text { Good work } \\
\text { team }\end{array}$ & 4.36 & Good work team & 4.45 & $\begin{array}{c}\text { Further financial } \\
\text { reward }\end{array}$ & 4.1 & Basic salary & 4.19 \\
\hline Basic salary & 4.34 & Job security & 4.39 & Recognition & 4.1 & $\begin{array}{c}\text { Further financial } \\
\text { reward }\end{array}$ & 4.18 \\
\hline Job security & 4.3 & $\begin{array}{c}\text { Fair appraisal } \\
\text { system }\end{array}$ & 4.39 & Work performance & 4.09 & Recognition & 4.17 \\
\hline $\begin{array}{l}\text { Further } \\
\text { financial } \\
\text { reward }\end{array}$ & 4.16 & Basic salary & 4.38 & $\begin{array}{l}\text { Communication in } \\
\text { the workplace }\end{array}$ & 4.07 & $\begin{array}{l}\text { Supervisor's } \\
\text { approach }\end{array}$ & 4.12 \\
\hline $\begin{array}{c}\text { Work } \\
\text { performance }\end{array}$ & 4.15 & $\begin{array}{l}\text { Communication in } \\
\text { the workplace }\end{array}$ & 4.29 & $\begin{array}{l}\text { Moving up } \\
\text { corporate ladder }\end{array}$ & 4.04 & $\begin{array}{l}\text { Stress /elimitation } \\
\text { of stress in the } \\
\text { workplace/ }\end{array}$ & 4.12 \\
\hline $\begin{array}{l}\text { Work object } \\
\text { and type of } \\
\text { work }\end{array}$ & 4.11 & $\begin{array}{l}\text { Further financial } \\
\text { reward }\end{array}$ & 4.25 & $\begin{array}{l}\text { Work object and } \\
\text { type of work }\end{array}$ & 4.02 & $\begin{array}{l}\text { Moving up } \\
\text { corporate ladder }\end{array}$ & 4.11 \\
\hline $\begin{array}{c}\text { Communication } \\
\text { in the } \\
\text { workplace }\end{array}$ & 4.09 & $\begin{array}{l}\text { Stress /elimitation } \\
\text { of stress in the } \\
\text { workplace/ }\end{array}$ & 4.21 & $\begin{array}{c}\text { Fair appraisal } \\
\text { system }\end{array}$ & 4.02 & Free time & 4.1 \\
\hline $\begin{array}{l}\text { Opportunity to } \\
\text { apply one's } \\
\text { own ability }\end{array}$ & 4.08 & $\begin{array}{l}\text { Work object and } \\
\text { type of work }\end{array}$ & 4.19 & Competences & 4.02 & $\begin{array}{c}\text { Region's } \\
\text { development }\end{array}$ & 4.1 \\
\hline
\end{tabular}

The following analysis, which is summarized in part 2 of Table 3, deals with employees in the sphere of transportation and logistics in the Peking Municipality. The relational motivation factors, like for example good work team, the atmosphere and communication at the workplace took the first positions again, both among men and women. Employees care about the atmosphere and the relations at the workplace. Pleasing environment and contentment at the workplace can motivate them to higher performance. Employees better concentrate on their work, are more productive and more efficient. As we can see, there is an obvious difference between men and women. Men care about both, the relational motivation factors and the work motivation factors. They are motivated to better performance if they have certain authorities and are informed on the work procedures and the object of the performed work. Women, on the other hand, want to avoid work stress; they want to eliminate it to the minimum. They are motivated by the approach of their superiors. Better results come with their support. Free time and the region development is a substantial motivation factor for women. With sufficient regeneration they are able to show their abilities and skills in the performance of their work task to the full extent.

\subsection{Analysis by means of the Student's T-test}

We applied the Student's T-test, which is applicable to the calculation of the differences between averages to the testing of the differences between the employees of the two countries. We analysed the motivation preferences of employees of transporting and logistic companies in the Czech Republic and in the Peking Municipality (PRC) in our Ttest. We tested how the individual motivation factors influence the employees in the two different countries and we tried to find out whether these factors are statistically significant or whether at least their difference is statistically significant. 
Table 4. Analysis of Czech employees and employees from the Peking Municipality by means of the Student's T-test. Source: authors

\begin{tabular}{|c|c|c|c|c|c|c|}
\hline & $\mu \mathrm{CR}$ & $\mu \mathrm{PRC}$ & $\begin{array}{l}\text { standard } \\
\text { deviation } \\
\text { CR } \\
\end{array}$ & $\begin{array}{l}\text { standard } \\
\text { deviation } \\
\text { PRC }\end{array}$ & F test & P level \\
\hline Atmosphere & 4.48 & 4.08 & 0.744 & 0.947 & 1.620 & 0.000 \\
\hline Team & 4.40 & 4.04 & 0.817 & 0.955 & 1.366 & 0.000 \\
\hline Further reward & 4.20 & 3.91 & 0.875 & 1.008 & 1.327 & 0.000 \\
\hline Physical efforts & 3.69 & 4.07 & 0.994 & 0.969 & 1.053 & 0.328 \\
\hline Job security & 4.35 & 3.94 & 0.803 & 1.033 & 1.655 & 0.000 \\
\hline Communication & 4.19 & 3.97 & 0.936 & 1.024 & 1.196 & 0.000 \\
\hline Name of the company & 3.83 & 3.85 & 1.064 & 1.030 & 1.067 & 0.218 \\
\hline $\begin{array}{l}\text { Opportunity to apply } \\
\text { one's own abilities }\end{array}$ & 4.04 & 4.01 & 0.914 & 1.019 & 1.242 & 0.000 \\
\hline Work object and type of work & 4.14 & 4.05 & 0.821 & 1.036 & 1.594 & 0.000 \\
\hline Communication of the result & 3.92 & 3.97 & 0.958 & 1.047 & 1.194 & 0.000 \\
\hline Working hours & 4.03 & 3.92 & 0.963 & 1.003 & 1.085 & 0.106 \\
\hline Work environment & 4.01 & 4.01 & 0.906 & 0.999 & 1.215 & 0.000 \\
\hline Work performance & 4.10 & 3.99 & 0.850 & 1.033 & 1.476 & 0.000 \\
\hline Career ladder & 3.88 & 3.89 & 0.915 & 1.028 & 1.262 & 0.000 \\
\hline Authorities & 3.79 & 4.03 & 0.970 & 0.972 & 1.004 & 0.934 \\
\hline Prestige & 3.75 & 4.14 & 0.996 & 0.956 & 1.085 & 0.119 \\
\hline Management approach & 4.44 & 4.11 & 0.775 & 0.996 & 1.651 & 0.000 \\
\hline Decision making & 4.00 & 3.94 & 0.914 & 1.033 & 1.278 & 0.000 \\
\hline Self-actualization & 4.00 & 3.97 & 0.931 & 1.024 & 1.210 & 0.000 \\
\hline Social benefits & 3.84 & 3.85 & 0.992 & 1.030 & 1.078 & 0.138 \\
\hline Appraisal & 4.21 & 4.01 & 0.975 & 1.019 & 1.093 & 0.080 \\
\hline Safety & 4.13 & 4.05 & 0.964 & 1.036 & 1.157 & 0.004 \\
\hline Psychical stress & 3.90 & 3.97 & 1.002 & 1.047 & 1.092 & 0.081 \\
\hline Vision of the company & 3.80 & 3.92 & 1.037 & 1.003 & 1.070 & 0.199 \\
\hline Region development & 3.67 & 4.01 & 1.101 & 0.999 & 1.216 & 0.000 \\
\hline Education & 4.05 & 3.99 & 0.964 & 1.033 & 1.149 & 0.006 \\
\hline The environment & 3.65 & 3.89 & 1.113 & 1.028 & 1.172 & 0.003 \\
\hline Free time & 3.93 & 4.03 & 1.012 & 0.972 & 1.084 & 0.124 \\
\hline Recognition (work) & 3.90 & 4.14 & 1.024 & 0.956 & 1.146 & 0.009 \\
\hline Basic salary & 4.36 & 4.11 & 0.870 & 0.996 & 1.310 & 0.000 \\
\hline
\end{tabular}

Note: Statistically significantly differences are highlighted in green.

The analysis by means of the Student's T-test (Table 4) revealed the fact that a lot of the examined motivation factors are statistically significantly different. We can particularly see a statistically significant difference in the motivation factors like the atmosphere at the workplace, the work team, further financial reward, the physical efforts at work, the job security, communication at the workplace, the work object and type of work, working hours, work performance, authorities, prestige, management approach, fair appraisal, safety at work, company vision, region development, the environment, free time, recognition and the basic salary. The influence of the above-mentioned motivation factors on employees differ in the two countries.

The analysis also revealed factors that do not differ statistically significantly and their influence on employees is nearly identical in both the countries. These factors are: the name of the company, the opportunity to apply one's own abilities, communication of the achieved results, the work environment, the career ladder, decision making, selfactualization, social benefits, psychical stress, education and personal growth. 


\section{Conclusion}

Each human and so each employee as well, is unique. He/she tries to satisfy his/her needs and desires. We can expect people from different countries to have different needs. We tried to give an insight into the difference between employees from the Czech Republic and employees from the Peking region that work in the sphere of transportation and logistics.

The results show that the relational motivation factors most influence the performance of employees in the Czech Republic, but those in the Peking Municipality as well. The differences between the employees are obvious. Comparison between men from the Czech Republic and men from the Peking Municipality led us to a conclusion that men in the Czech Republic are motivated to high work performance by the basic salary and by the job security. Men in the Peking Municipality on the other hand put stress on recognition, authorities and the career ladder. The basic salary is of course a strong motivation factor for them as well. Upon comparison of women in the Czech Republic and those in the Peking Municipality we can definitely conclude that women in both the countries care about recognition, superior's approach and the effort to eliminate stress at the workplace. The differences that we can see are, like among men, in the job security. Free time and the region development are other obviously different factors. Women from the Peking Municipality care more about free time, recreation and regeneration. The efforts for the development of the region they live in can motivate them to increased work performance.

The presented research results can provide an insight into the issue of work motivation in the sphere of transportation and motivation and thus create a portfolio for a proposal of motivation programmes. A lot of companies expand to or cooperate with China at present. It is therefore more than important to learn about the basic cultural differences, but also the differences of preferences among employees from the two cultures.

This research was supported by VEGA No. 1/0024/17, Computational Model of Motivation.

This paper is supported by the research project "From horse-drawn railway to intermodal transport" within Visegrad Fund.

\section{References}

1. N. Bontis, Technology Management 18, 621-642 (1999)

2. K.E. Sveiby, The New Organizational Wealth: Managing \& Measuring Knowledgebased Assets Barrett-Kohler (San Francisco, CA, USA, 1997)

3. D. Weberová, P. Štarchoň, L. Ližbetinová, Vision 2020: Innovation Management, Development Sustainability, and Competitive Economic Growth - Proceedings of the 28th International Business Information Management Association Conference (2016)

4. M. Vetrakova, L. Smerek, E \& M Ekonomie a Management 19, 1, $62-73$ (2016)

5. R. Zámečník, Marketing and Management of Innovations 4, 325-341 (2016)

6. E. Carson, et al., Journal of Intellectual Capital 5, 3, 443-461 (2004)

7. P.R. Massingham, W.Y.L. Tam, Journal of Intellectual Capital 16, 2, 390-418 (2015)

8. C. Argyris, Dorsey Press. Michigan, 60-10149, 89-126 (1960)

9. D.M. Rousseau, Journal of Occupational and Organizational Psychology 74, 4, 511 541 (2001)

10. S.P. Robbins, T.A. Judge, Organizational behavior. Global and Southern African Perspectives, 234 p. (South Africa: Cape Town, 2008) 
11. K. Stachová, Z. Stacho, G. Pajtinková Bartáková, Business: Theory and Practice 16, 264-270 (2015)

12. J. Drábek, S. Lorincová, J. Javorčíková, Issues of human resource management, 113136 (2017)

13. S. Lorincová, J. Schmidtová, J. Javorčíková, Drvna Industrija 67, 4, 351-362 (2016)

14. H. Urbancová, J. Urbanec, Acta Universitatis Agriculturae et Silviculturae Mendelianae Brunensis 60, 4, 387-396 (2012),

15. A. Olšovská, L. Mura, M. Švec, Polish Journal of Management Studies 13, 110-120, 2016 ,

16. A. Kucharcikova, L. Konusikova, E. Tokarcikova, Communications: Scientific Letters of the University of Zilina 18, 49-54 (2016)

17. I. Kubasakova, R. Kampf, O. Stopka, Communications: Scientific Letters of the University of Zilina 16, 2, 9-13 (2014)

18. J. Ližbetin, L. Černá, M. L'och, Naše more 62, 147-152 (2015), DOI 10.17818/NM/2015/SI11

19. E. Nedeliakova, M. Panak, International Conference on Engineering Science and Management, 195-198 (Zhengzhou, China, 2016)

20. Czech Statistical Office, Available online: https://www.czso.cz/ssu (2016)

21. Slovak Statistical Office, Available online: https://www.czso.cz/ssu (2016)

22. R. Myšková, Scientific Papers of the University of Pardubice 6, 75-79 (2001)

23. A. Grenčíková, J. Španková, Proceedings of the 1st International Conference Contemporary Issues in Theory and Practice of Management, 103-108 (Czestochowa, Poland, 2016)

24. L. Mura, V. Gašparíková, Acta Universitatis Agriculturae et Silviculturae Mendelianae Brunensis 58, 3, 157-164 (2010)

25. G. Hofstede, Cultural consequences: international differences in work-related values (1980)

26. M. Potkány, L. Krajčírová, Procedia Engineering 192, 731-736 (2017)

27. M. Hitka, Organisational Culture and Motivation as Instigators for Employee Engagement, (ES TU Zvolen, Slovak Republic, 2009)

28. J. Gravetter, Frederick, L.B. Wallnau, Statistics for the behavioral sciences, Cengage Learning (2016) 